Mouratbek Ch. KOZHOBEKOV

Kirghizstan-Turkey Manas University

Bıshkek, Kirghizstan

k_murat2001@mail.ru

\section{STATE APPARATUS IN THE KIRGHIZ KHAGANATE}

In this article are being observed the role and the meaning, and the structure of the state's structure during the Kirghiz Khaganate. The state's governmental structure plays a great role in the the implementation of state power and its functionality which can determine the level of society development. In the historical science there is no ambiguous assessment of the history of the Kirghiz Republic state's administration. Some historians are hesitating question on the Chinese authors' reports on the structure of power in the Kirghiz state. However, the results of comparison the Chinese sources with the materials of Yenisei runic writing make it possible to assess positively the presence of public administration in the Kirghiz Kaganate. The apparatus of the Kirghiz Kaganate state administration was created by analogy Tang China, but at the same time there are some features in the structure and titles of power. Apparently, this moment contains the result of adaptation of the foreign origin power organization to local conditions.

Keywords: Kirgiz, Kirgiz khanate, Tang China, state Ключевые слова: кыргыз, Кыргызский каганат, administration, government, Qaghan, van, total, Танский Китай, государство, аппарат управления, minister, title

\author{
КОЖОБЕКОВ Муратбек Чалакеевич \\ Кыргызско-Турецкий университет «Манас» \\ г. Бишкек, Кыргызстан \\ k_murat2001@mail.ru
}

ГОСУДАРСТВЕННЫЙ АППАРАТ В КЫРГЫЗСКОМ КАГАНАТЕ

В статье рассматривается роль и значение, а также структура аппарата государственного управления в Кыргызском каганате. Аппарат управления играет важную роль в осуществлении государственной власти, и по ее функциональности можно определить уровень развития общества. В исторической науке нет однозначной оценки истории создания государственного аппарата управления у кыргызов. Некоторые историки ставят под сомнение сообщения китайских авторов о структуре власти в кыргызском государстве. Однако результаты сопоставления китайских источников с материалами Енисейской рунической письменности дают возможность положительно оценить наличие органов государственного управления в Кыргызском каганате. Аппарат государственного управления в Кыргызском каганате был создан по аналогии с Танским Китаем, но в то же время имеются некоторые особенности в структуре и титулатуре власти. Видимо, данный момент содержит результат адаптации властной организации иностранного происхождения к местным условиям.

As the Kirghiz country was governed by a Qaghan in the Middle Ages scholars define the Kirghyz state by the term "khaganate". However, there are contradictory facts in history which may add clarification to the name of the Kirghiz country. The fact of giving states the names connected with the leader title is frequent in the history, for example, the state names Kingdom of Franks, Duchy or Kingdom of Rus' are known to be given according to the power type and the title of the state governor. Particularly this tendency is typical for the states of the middle ages.

The Turkic (T'u-chueh) and Uighur states in Central Asia were called khaganate according to the form of power as well. If to analyze the power system of the Kirghiz country we face some doubts about the propriety of the term "khaganate" usage otherwise there is a necessity of clarifying the state name. These doubts first of all come from the data connected with the Kirghiz state power system and state governor's title. The Kirghiz country's government power apparatus along with a governor's title were entirely different from other Turkic-speaking peoples' states. According to Chiu T'ang-shu written sources the state structure of the Kirghiz Khaganate was formed similarly to the government power apparatus of Tan in the Chinese Empire. The particular attention should be paid to the fact that there was no such a government structure among the Turkic-speaking states. A number of scholars expressed concern about the peculiarities observed in the Kirghiz state. A.N. Bernshtam analyzed the following information taken from Chinese written sources: "Lord's home is protected, consists of cabins with kiyiz (felt rugs) and called Midichji. Lower chiefs live in small cabins. The army is formed from all clans. Dependent peoples pay taxes by lynx and squirrels' fells" [5, p. 352) and came to the conclusion that the Chinese in order to understand other peoples' social structure put punishment according to their own development level [3; p. 75; pp. 290-291]. In addition A.N. Bernshtam had some doubts about the data written in Chinese written resources: "lower chiefs are divided into six 
layers, they are ministers, senior chiefs, leaders, clerks, chiefs and daghans". There are seven ministers, three senior chiefs, ten leaders. All of them are responsible for army control. The number of clerks is fifteen; chiefs and daghans are out of power" [5, p. 352]. As there is no such information in the Kirghiz runic texts the scholar considers them as temporary news and generally contradicts the written sources data [4, p. 189].

Indeed it is easy to negate some information due to the insufficient amount of data. However it is necessary to keep in mind that each source has great informational significance. Undoubtedly the Chinese author who described the Kirghiz state's government power structure relied on the sources and people with the sense of responsibility. In addition it is possible to notice some similarities between the informational sources describing the Kirghiz state's government power structure made by the Chinese author causing A.N. Bernshtam's doubts and runic monuments. Now we will try to analyze all the problems mentioned above.

The distinctive feature of the Kirghiz state political structure is naming the state leader differently in different languages. In the Kirghiz runic written monuments the state leader is called "khan" <... "kan". Apparently in the Kirghiz political terminology the name "khan" was used to show the highest power leader. For example they called the Chinese emperor Tabgach khan, Tibetan tsenpo - Tuput khan [11, pp. 29, 57 - 58; 7, pp. 262-266].

If we take the Orhon texts devoted to Turkic rulers "a strong Qaghan of the Kirghiz" has been mentioned Qyrqyz küč (lig) qayan [10, p. 62; 21, p. 106]. In the Chinese sources it is written that if the state ruler is called Ajo (governor) he is titled as Ajo [5, p. 352]. It is also known that according to the Chinese sources sometimes the Kirghiz governor was called van, in other cases keghan' [12, p. 282; 15, p. 67-68]. In the works of Arab-Persian authors the Kirghiz leader was named hirhiz hakany [13, p. 41) Khirkhiz-khaqan <...> Qirqiz-khan [20, p. 259].

According to the present-day scientific research results the term "Qaghan" used in government system of the Turkic-speaking ethnos was borrowed from Juan-juan vocabulary. Later it turned into the highest government title of the Turkic and Mongolian peoples. There is one more particularly significant issue for the science related to the Muslim scholars' ideas about the Qaghan title. For example al'-Biruni determined the title "hakan" analogically with the Turkic, Hazar and Toquzghuz's title "malik (han)" (Biruni, 1957: 183). Al-Horezmi mentioned that the term "qhan" appeared from the term "hakan" [14, p. 135].

So, in accordance with the language peculiarities perception of different peoples the fact that the Kirghiz Khaganate government leaders were called "self-serving power" in different ways has been testified in written sources. The Kirghiz people's naming their governor "qhan" was equal to the "qaghan" title used by the Turkic-speaking peoples.

In accordance with the idea of the sinologist E.I. Kychanov among, all the Turkic-speaking Khaganates the Kirghiz government power apparatus was very similar to the Chinese administrative structure [9, p. 65]. If to rely E.I. Kychanov's investigation the Kirghiz Khaganate lower chiefs division into six layers named "lyu den" converges with the "lyu bu" (six ministries) system used in the government system of the Tang dynasty [9, p. 65].

The "six layer" division consisted of ministries of management, ceremonial, justice (punishment system), finance, and personnel, military and public activities [5, p. 352; 9, p. 65; 8, p. 56). N.V. Kyuner translated the oral records Tai Chi Ping Huanyuy and introduced the titles of Ju - Syanb, du - du, chiang - chun, da - qian [8, p. 56].

According to E. I. Kychanov's idea such a government apparatus system was a "particularly flexible well-tested system and would able to meet all state requirements even at present time" [9, pp. 65-66].

Similarly to the Chinese Tang the Kirghiz government was ruled by "zaixiang" (chancellor, vizier, Prime Minister). There were seven zaixiangs in the country and each of them ruled local regions in the state. One of seven zaixiangs was considered to be the chief while the rest ruled separate "dans".

The process of ruling six dans by six zaixiangs is particularly harmonious with the lines in the Kirghiz records "alty bag budunka bag artim» which means "I was a headman (bek) in six regions". In the Uyuk Tarlac records the epitaph hero's name was El Tugan with a title "tutuq" (totoq) [11, p. 11]. The title of "tutuq' used by the Turkic-speaking ethnos appeared from the an- 
cient Chinese term "tu-tu" (tuo-tuok). According to Ecsedy's idea the Turks mastered this Chinese title in their government system till 558 [18, p. 85]. In the Kirghiz records it is written as "tutk" and "tutuk" in full. The Kirghiz might have accepted this title "Tuo-tuok" from the Turkicspeaking peoples. If to pay attention to the "tutuk" term's distribution area it is necessary to mention that this term had been widely spread in a settled field.

In the Chinese written sources it is written about three supreme authority leaders [5, p. 352]. E. I. Kychanov regards them as "tutuktuk" or three administrative divisions [9, p. 65].

In accordance with the information mentioned above the Kirghiz Khaganate was formed of "alty bektik" (six regions ruled by bek (headman)); at the time it was joined into three "tutuktuk" (administrative division). The triple system was suitable for the Central Asian nomadic government system and met the military-administrative requirements. For the peoples leading nomadic and semi nomadic lifestyle the triple system was historically well-tested and served as a union for the flexible government coordination. The results of the Kirghiz runic records analysis basically have strengthened the main point of view mentioned above. According to the forth Chakul hero records it was testified that the state was "red flag tutuk" and he was not satisfied with his Heaven state, his beks (leaders) [11, pp. 38-39].

Due to the information mentioned above we may note that "alty bektik" (six regions ruled by "beks" (headmen)) was formed based on the local generic principles; the triple ("uch tutuktuk") government system was formed with the help of the military-administrative right, left and central alliance.

Due to the Kirghiz runic records analysis it was determined that the "tutuk" title was the highest in the supreme power of the Kirghiz khaganate. The Kejilig-hobu records hero Komul Oge described his way to the throne in the following way: "I became the counselor of state ("oge") at the age of thirty. When I was forty I got the title of Tutuk and started to govern my people" [11, pp. 81-82].

In the Kirghiz khaganate the people of higher position (egeler) were different from ordinary people. The title of Tutuk was given to a person worthy of this post by the Khan and as a symbol of power he was given a white golden belt» [11, pp. 94-95].

It is possible that the title of "Oge" denoted the counselor in the central and local state administration [2, p. 99].

In the Ancient Turkic Dictionary vocabulary the term "Oga" is interpreted as -

sage, thinker [6, p. 379]. According to scholars' opinion Og Ug (Uga) "Өг” = "ҮГь" (ҮГьА) denotes sage, arbiter, workman See [2, p. 99]

In the Kirghiz state the local authorities' activities were controlled by the "chji shi" - observers from the central government system [5, p. 353; 9, p. 65]. The term mentioned in the Chinese titles converges with the title "chigshi" in the Kirghiz runic written records. This title appeared from the Chinese title of "tsy shi" [18, p. 86]. In the Chinese sources they controlled the provinces' activities with the emperor's order.

The Chinese title of "Tsy-shi" tz'ŭ - shih (ts'iäk - şi) - čegši [11, p. 45; 18, pp. 86-87] was accepted in the Kirghiz government system as "chigshi".

For the country with social, political, and economical systems the statistical service plays an important role. In addition, to conduct internal and external policy of the Kirghiz Khaganate the Chjanshi Secretariat consisting of fifteen people [5, p. 353; 9, p 55; 16, p. 164] worked. In the historical literature the "chzhanshini" were translated as a chief Secretary [16, p. 164].

This title was accepted by the Turkic and Mongolian peoples as chang - shih (tiang - şi) čäńši [18, p. 88]. In the Kirghiz runic records the title of Čäńši is written as "Chanshy" [11, pp. 6061]. Some turkologists regard this term as a name of a person [6, p. 139]. H.N. Orkun reads a term defining the Uibat records' hero as a person name as well. [21, pp. 552-553].

Nevertheless according to the Uibat written records the name "chanshy" denotes the important title in the Kirghiz khanate. In accordance with E. I. Kychanov's investigation the Chjanshi Secretariat in the Kirghiz Khaganate consisting of fifteen people occupied higher position in the state rather than secretaries at present time [9, p. 65].

In the Kirghiz Khaganate the tax policy was controlled by tarkans, their amount was not clarified in the written sources [5, p. 353]. All the people of the Kirghiz state paid taxes to the 
central government. Also all the young men were obliged to join the army. Perhaps the men who reached the adult age paid taxes and according to their amount the number of "tarkans" serving the state was estimated.

The soldiers were led by famed "sanuns". J. Hamilton notes that Turkic peoples borrowed this title from the Chinese Jianjun title by changing the form tsiang - kiun, tsiang - kịan into

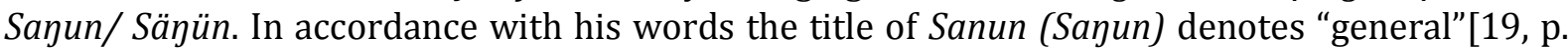
155]. F. W. Cleaves considers this term as it is known that the Chinese title "Tsiang-kiun" turned into ĵangjun" - "general» in the Mongolian military terminology [17, p.23].

In general, having summarized all the facts mentioned above we may conclude that the Kirghiz Khaganate became a centralized state. The formation of state government structure according to its agricultural and cultural type allowed the country potestades process to develop without any changes. The excellent knowledge of the state leaders in educational and personnel policies served to keep even balance of the power structure and strengthen intergovernmental relations between the Kirghiz Khaganate and Central Asian developed states.

\section{БИБЛИОГРАФИЧЕСКИЕ ССЫЛКИ}

1. Бируни А.Р. Избранные произведения. Т. 1. Памятники минувших поколений. - Ташкент: Изд-во АН Уз.ССР, 1957.- 487 с.

2. Батманов И.А., Арагачи З.Б., Бабушкин Г.Ф. Современная и древняя Енисейка. - Фрунзе: Издво АН Кирг. ССР, 1962. - 249 с.

3. Бернштам А.Н. История кыргыз и Кыргызстана с древнейших времен до монгольского завоевания // Рукописный фонд Национальной Академии наук Кыргызской Республики. Инв. № 128. - 334 с.

4. Бернштам А.Н. Избранные труды по археологии и истории кыргызов и Кыргызстана. Т. II / Сост. К. Ташбаева, Л. Ведутова. - Бишкек: Айбек, 1998. - 704 с.

5. Бичурин Н.Я. Собрание сведений о народах, обитавших в Средней Азии в древние времена. Т. 1. - М.; Л.: Изд-во АН СССР, 1951. - 379 с.

6. Древнетюркский словарь. - Л.: Наука, 1969. - 677 с.

7. Кляшторный С.Г. Стелы Золотого озера (К датировке енисейских рунических памятников) // Turkologica. - Л., 1976. - С. 258-267.

8. Кюнер Н.В. Китайские известия о народах Южной Сибири, Центральной Азии и Дальнего Востока. - М.: Изд-во вост. лит., 1961. - 392 с.

9. Кычанов Е.И. Аппарат управления у енисейских кыргызов (по китайским сведениям) // Источники по средневековой истории Кыргызстана и сопредельных областей Средней и Центральной Азии. - Бишкек, 1991. - С. 64-66.

10. Малов С.Е. Памятники древнетюркской письменности. Тексты и исследования. - М.; Л.: Издво АН СССР, 1951. - 452 с.

11. Малов С.Е. Енисейская письменность тюрков. Тексты и переводы. - М.; Л.: Изд-во АН СССР, 1952. - $116 \mathrm{c}$.

12. Малявкин А.Г Танские хроники о государствах Центральной Азии: Тексты и исследования. - Новосибирск: Наука, 1989. - 432 с.

13. Материалы по истории киргизов и Киргизии. Вып. I / Отв. ред. В.А. Ромодин. - М.: Наука, 1973. - $280 \mathrm{c}$.

14. Новосельцев А.П. Хазарское государство и его роль в истории Восточной Европы и Кавказа. - М.: Наука, 1990. - 266 с.

15. Супруненко Г.П. Документы об отношениях Китая с енисейскими кыргызами в источнике IX века «Ли Вэй-гун Хойчан Ипииь Цзи». Изв. АН Кирг.ССР. Сер. обществ. наук. - Фрунзе, 1963. - Т. 5. - Вып. 1. - С. 67-81.

16. Таскин В.С. Материалы по истории сюнну. Вып. 1. - М.: Наука, 1968. - 178 с.

17. Cleaves F.W. The Colophon to the Bolor Erike // Harvard Journal of Asiatic Studies. - 1968. - Vol. 28. - Pp. 5-43.

18. Ecsedy H. Old Turkic Titles of Chinese Origin, Acta Orientalia Academiae Scientiarum Hungaricae. - 1965. - Vol. 18. - No. 1/2. - Pp. 83-91.

19. Hamilton J.R. Les Ouïghours À l'épogue des Cing Dinasties. D’après Les Documents Chinois. - Paris: Presses universitaires de France, 1955. - XI. - 201 p. 
20. Minorsky V. Addenta to the Hudud al - Alam, Bulletin of the School of Oriental and African Studies, University of London. - 1955. - Vol. 17. - No. 2. - Pp. 250-270.

21. Orkun H.P. Eski Türk Yazitlari. - Ankara, 1988. - 962 p.

\section{REFERENCES}

1. Biruni A.R. Izbrannye proizvedeniya. [Selected works.]. Tom 1. Pamyatniki minuvshih pokolenij. Tashkent: Izd-vo AN Uz.SSR, 1957. 487 p. (In Russ.).

2. Batmanov I.A., Aragachi Z.B., Babushkin G.F. Sovremennaya i drevnyaya eniseika. [Modern and ancient Yeniseika]. Frunze: Izd-vo AN Kirg. SSR, 1962. 249 p. (In Russ.).

3. Bernshtam A.N. Istoriya kyrgyz i Kyrgyzstana s drevnejshchih vremen do mongol'skogo zavoevaniya. [The history of Kyrgyzstan and Kyrgyzstan from ancient times to the Mongol conquest]. Rukopisnyj fond Nacional'noj Akademii nauk Kyrgyzskoj Respubliki, Inv. No. 128. 334 p. (In Russ.).

4. Bernshtam A.N. Izbrannye trudy po arheologii i istorii kyrgyzov i Kyrgyzstana. [Selected works on archeology and history of Kyrgyz and Kyrgyzstan]. T. II, Sost.: K. Tashbaeva, L. Vedutova. Bishkek: Ajbek, 1998. 704 p. (In Russ.).

5. Bichurin N.Ya. Sobranie svedenij o narodah, obitavshchih v Srednej Azii v drevnie vremena. [A collection of information about the peoples inhabiting Central Asia in ancient times]. T. 1. M.; L.: Izd. Akademii Nauk SSSR, 1951. 379 p. (In Russ.).

6. Drevnetyurkskij slovar. [Ancient Turkic dictionary]. L.: Nauka, 1969. 677 p. (In Russ.).

7. Klyashtornyj S.G. Stely Zolotogo ozera (K datirovke enisejskih runicheskih pamyatnikov). [The stelae of the Golden Lake (To the dating of the Yenisei runic monuments)]. Turkologica. L., 1976. Pp. 258-267. (In Russ.).

8. Kyuner N.V. Kitajskie izvestiya o narodah Yuzhnoj Sibiri, Central'noj Azii i Dal'nego Vostoka. [Chinese news about the peoples of Southern Siberia, Central Asia and the Far East]. M.: Izd-vo vost. lit., 1961. 392 p. (In Russ.).

9. Kychanov E.I. Apparat upravleniya u enisejskih kyrgyzov (po kitajskim svedeniyam). [Office of management of the Yenisei Kyrgyz (according to Chinese sources)]. Istochniki po srednevekovoj istorii Kyrgyzstana i sopredel'nyh oblastej Srednej i Central'noj Azii. Bishkek, 1991.Pp. 64-66. (In Russ.).

10. Malov S.E. Pamyatniki drevnetyurkskoj pis'mennosti. Teksty i issledovaniya [Monuments of ancient Turkic writing. Texts and research]. M.; L.: Izd. AN SSSR, 1951. 452 p. (In Russ.).

11. Malov S.E. Enisejskaya pis'mennost' tyurkov. Teksty i perevody [The Yenisei script of the Turks. Texts and translations]. M.; L.:Izd. AN SSSR, 1952. 116 p. (In Russ.).

12. Malyavkin A.G Tanskie hroniki o gosudarstvah Central'noj Azii: Teksty i issledovaniya [Tang chronicles about the states of Central Asia: Texts and research]. Novosibirsk: Nauka, 1989. 432p. (In Russ.).

13. Materialy po istorii kirgizov i Kirgizii [Materials on the history of Kyrgyz and Kyrgyzstan]. Vyp. I. Otv. red. V.A. Romodin. M.: Nauka, 1973. 280 p. (In Russ.).

14. Novosel'cev A.P. Hazarskoe gosudarstvo i ego rol' v istorii Vostochnoj Evropy i Kavkaza. [The Khazar state and its role in the history of Eastern Europe and the Caucasus]. M.: Nauka, 1990. 266 p. (In Russ.).

15. Suprunenko G. P. Dokumenty ob otnosheniyah Kitaya s enisejskimi kyrgyzami v istochnike IX veka «Li Vehj-gun Hojchan Ipii' Czi». [Documents on China's relations with the Yenisei Kyrgyz in the source of the Century "Li Wei-gun Hohan Ipi Ji"]. Izv. AN Kirg.SSR. Ser. obshchestv, nauk. Frunze, 1963, t. 5, vyp. 1. Pp. 67-81. (In Russ.).

16. Taskin V.S. Materialy po istorii syunnu. [Materials on the history of the Huns]. Vyp.1. M.: Nauka, 1968. 178 p. (In Russ.).

17. Cleaves F.W. The Colophon to the Bolor Erike. Harvard Journal of Asiatic Studies, 1968. Vol. 28. Pp. 5-43. (In Eng.).

18. Ecsedy H. Old Turkic Titles of Chinese Origin, Acta Orientalia Academiae Scientiarum Hungaricae, Vol. 18, No. 1/2 (1965), pp. 83-91. (In Eng.).

19. Hamilton J.R., Les Ouïghours À l'épogue des Cing Dinasties. D'après Les Documents Chinois, Paris: Presses universitaires de France, 1955. XI, 201 p. (In French).

20. Minorsky V. Addenta to the Hudud al - Alam, Bulletin of the School of Oriental and African Studies, University of London, Vol. 17, No. 2 (1955), pp. 250-270. (In Eng.).

21. Orkun H. P. Eski Türk Yazitlari. Ankara, 1988. 962 p. (In Turk.) 


\section{Information about the author:}

Mouratbek Ch. Kozhobekov, Candidate of Historical Sciences, Associate Professor, KirghizstanTurkey Manas University, Bishkek, Kirghizstan

k_murat2001@mail.ru

Received: 25.03.2018

For citation: Kozhobekov M.Ch. State apparatus in the Kirghiz khaganate. Historical and SocialEducational Idea. 2018. Vol . 10. no. 2-2. Pp. 28-33. doi: 10.17748/2075-9908-2018-10-2/2-28-33. (in Russ)

\section{Информация об авторе:}

Кожобеков Муратбек Чалакеевич, кандидат исторических наук, доцент, КыргызскоТурецкий университет «Манас», г. Бишкек, Кыргызстан k_murat2001@mail.ru

Получена: 25.03.2018

Для цитирования: Кожобеков М.Ч. Государственный аппарат в Кыргызском каганате. Историческая и социально-образовательная мысль. 2018. Том. 10 . № 2-2 . с.28-33. doi: 10.17748/2075-9908-2018-10-2/2-28-33. 